\title{
New genes of Xanthomonas citri subsp. citri involved in pathogenesis and adaptation revealed by a transposon-based mutant library Marcelo L Laia*1, Leandro M Moreira ${ }^{2}$, Juliana Dezajacomo ${ }^{1}$, Joice B Brigati ${ }^{1}$, Cristiano B Ferreira ${ }^{1}$, Maria IT Ferro ${ }^{1}$, Ana CR Silva ${ }^{3}$, Jesus A Ferro ${ }^{1,3}$ and Julio CF Oliveira ${ }^{1,4}$
}

Address: ${ }^{1}$ Universidade Estadual Paulista, UNESP, Campus de Jaboticabal, Departamento de Tecnologia, 14884-900, Jaboticabal, SP, Brazil, ${ }^{2}$ Departamento de Bioquímica, Instituto de Química, Universidade de São Paulo, USP, Av. Lineu Prestes 748, Cx. Postal 05509-900, São Paulo, SP, Brazil, ${ }^{3}$ Alellyx Applied Genomics, Rua James Clerk Maxwell 320, 13069-380, Campinas, SP, Brazil and ${ }^{4}$ Universidade Federal de São Paulo, UNIFESP, Departamento de Ciências Biológicas, 09972-270, Diadema, SP, Brazil

Email: Marcelo L Laia* - marcelolaia@gmail.com; Leandro M Moreira - lmmorei@gmail.com; Juliana Dezajacomo - jdeza@fcav.unesp.br; Joice B Brigati - joicebiounesp@yahoo.com.br; Cristiano B Ferreira - chupado_unesp@yahoo.com.br; Maria IT Ferro - mitferro@fcav.unesp.br; Ana CR Silva - ana.rasera@alellyx.com.br; Jesus A Ferro - jesus@fcav.unesp.br; Julio CF Oliveira - jcycler@yahoo.com.br

* Corresponding author

Published: 16 January 2009

BMC Microbiology 2009, 9:12 doi:10.1186/147|-2180-9-12
Received: 12 September 2008

Accepted: 16 January 2009

This article is available from: http://www.biomedcentral.com/I47I-2/80/9/I2

(C) 2009 Laia et al; licensee BioMed Central Ltd.

This is an Open Access article distributed under the terms of the Creative Commons Attribution License (http://creativecommons.org/licenses/by/2.0), which permits unrestricted use, distribution, and reproduction in any medium, provided the original work is properly cited.

\begin{abstract}
Background: Citrus canker is a disease caused by the phytopathogens Xanthomonas citri subsp. citri, Xanthomonas fuscans subsp. aurantifolli and Xanthomonas alfalfae subsp. citrumelonis. The first of the three species, which causes citrus bacterial canker type $A$, is the most widely spread and severe, attacking all citrus species. In Brazil, this species is the most important, being found in practically all areas where citrus canker has been detected. Like most phytobacterioses, there is no efficient way to control citrus canker. Considering the importance of the disease worldwide, investigation is needed to accurately detect which genes are related to the pathogen-host adaptation process and which are associated with pathogenesis.
\end{abstract}

Results: Through transposon insertion mutagenesis, 10,000 mutants of Xanthomonas citri subsp. citri strain 306 (Xcc) were obtained, and 3,300 were inoculated in Rangpur lime (Citrus limonia) leaves. Their ability to cause citrus canker was analyzed every 3 days until 2 I days after inoculation; a set of 44 mutants showed altered virulence, with 8 presenting a complete loss of causing citrus canker symptoms. Sequencing of the insertion site in all 44 mutants revealed that 35 different ORFs were hit, since some ORFs were hit in more than one mutant, with mutants for the same ORF presenting the same phenotype. An analysis of these ORFs showed that some encoded genes were previously known as related to pathogenicity in phytobacteria and, more interestingly, revealed new genes never implicated with Xanthomonas pathogenicity before, including hypothetical ORFs. Among the 8 mutants with no canker symptoms are the hrpB4 and hrpX genes, two genes that belong to type III secretion system (TTSS), two hypothetical ORFS and, surprisingly, the htrA gene, a gene reported as involved with the virulence process in animal-pathogenic bacteria but not described as involved in phytobacteria virulence. Nucleic acid hybridization using labeled cDNA probes showed that some of the mutated genes are differentially expressed when the bacterium is grown in citrus leaves. Finally, comparative genomic analysis revealed that 5 mutated ORFs are in new putative pathogenicity islands.

Conclusion: The identification of these new genes related with Xcc infection and virulence is a great step towards the understanding of plant-pathogen interactions and could allow the development of strategies to control citrus canker. 


\section{Background}

Citrus canker is a disease caused by the phytopathogens Xanthomonas citri subsp. citri, X. fuscans subsp. aurantifolli and $X$. alfalfae subsp. citrumelonis [1]. Among the three phytopathogens, the Asiatic form (X. citri subsp. citri), which causes citrus bacterial canker type $A$, is the most widely spread and severe, attacking all citrus varieties [2]. In Brazil, form $\mathrm{A}$ is the most important, being found in practically all areas where citrus canker has been detected [3]. Similarly to most phytobacterioses, there is no efficient way to control citrus canker. The only way to eliminate the disease is through the eradication of sick plants, a procedure that brings significant economical losses. By law, in São Paulo State, the main citrus production area in Brazil, it is mandated to eliminate all plants around the focus of infection in a $30 \mathrm{~m}$ radius if the contaminated plants are less than $0.5 \%$ of the planting field and all plants in the planted field if the contaminated plants are more than $0.5 \%$. In the latter case, cultivation is then prohibited in the area for the next 3 years and there is no payment for lost production to the growers.

Considering the importance of the disease worldwide, especially for Brazil, a Brazilian group sequenced and annotated the complete genome of $X$. citri subsp. citri (Xcc) strain 306 [4], which causes citrus canker, and compared it with $X$. campestris pv. campestris strain ATCC 33913, the etiological agent of crucifer black rot. The citrus subspecies has 4,313 open reading frames (ORFs), of which $62.83 \%$ have been assigned function. In addition, Xcc also has two plasmids that have 115 genes, and for 55 $(47.82 \%)$ of them, no role has been proposed.

Although the genome of Xcc has been characterized and annotated, the inferences made based on in silico analyses require experimental investigation to accurately detect which genes are related to the pathogen-host adaptation process, and which are associated with pathogenesis itself. Therefore, functional genomics studies are necessary to elucidate the machinery required for pathogen installation and proliferation in plants, and the induction of citrus canker symptoms in the host. From the functional genomic perspective, large scale analysis of mutants by inoculation in host plants allows identification of the genes required for adaptation, pathogenesis and virulence, providing a best understanding of the colonization and infection potential of the bacteria.

In this work, using transposon insertion mutagenesis [5], a library containing 10,000 mutants of the citrus canker etiological agent $X$. citri subsp. citri strain 306 was prepared and 3,300 mutants were analyzed after individual inoculation of host plants. Eight mutants with absent pathogenicity and 36 mutants with reduced symptoms in planta, at varying intensities, were identified. Mutated genes were identified by sequencing the total DNA of the mutants with altered virulence, allowing the identification of the site of insertion of the transposon used for mutagenesis.

A random selection of these genes was immobilized on a nylon membrane array and expression profiles were analyzed in vivo through nucleic acid hybridization to labeled cDNA probes, using targets corresponding to wild Xcc strains multiplied in non-infective (Xcc multiplied in rich culture medium) or infective conditions (Xcc multiplied in a host plant). Finally, a comparative genomic analysis of each mutated ORF region from Xcc with other sequenced Xanthomonas genomes allowed the identification of five interesting genomic regions, with two being exclusive to Xcc. The unique characteristics presented by these five regions suggest that they are probably new pathogenicity islands [6] in Xcc.

The implications of the proteins encoded by these mutated ORFs in host adaptation and colonization processes and citrus canker symptoms induction are discussed.

\section{Results \\ Mutant analysis and in vivo pathogenicity test}

To identify and characterize genes involved in pathogenicity and virulence in $X$. citri subsp. citri isolate 306, a library of mutants was built through random transposon insertion. To determine whether transposon insertion affected the ability of Xcc to cause disease, 3,300 mutants of this library were individually inoculated in Rangpur lime (Citrus limonia) plantlets. Assuming the transposon is randomly distributed along the genome in a single-copy manner, the probability of finding one transposon insertion for a certain gene can be calculated by the formula: $P=$ $1-(1-X / G)^{n}$, where $P$ is the probability of finding one transposon insert within a given gene; $X$ is the length of the gene; $G$ is the length of the genome; and $n$ is the number of transposon inserts present in the population [7]. Based on the sequenced genome of citri 306, and considering the main chromosome and two plasmids, the average length of each ORF in the Xcc genome is 1,019 bp [4] and the probability of finding one transposon insert for a certain gene is up to $47 \%$. The mutants identified as having altered pathogenicity in this first round were re-inoculated and re-analyzed, resulting in a final 44 mutants showing some symptomatic variation. The mutants were grouped in five classes according to severity of the major symptoms: total absence of symptoms; watersoaking (ws); hyperplasia (hyp); necrosis (nec); and hypersensitive-like response (HR-l) [see Additional file 1].

The site of transposon insertion was determined by sequencing for all 44 mutants [see Additional file 1]. In 40 mutants the transposon was inserted inside an ORF and in 
four the insertion was at the 5'-end of the ORF, probably in the promoter region [see Additional file 1]. In addition, 5 ORFs were hit in two independent mutants (ORFs XAC0014, XAC1201, XAC1927, XAC3245 and XAC3263) and in two cases the same ORF was hit in three different mutants (ORFs XAC2047 and XAC2072), resulting in 35 different ORFs being hit. In all cases, mutants having a transposon insertion in the same ORF, irrespective of the insertion site, showed the same phenotype as determined by independent evaluations at three different times. Based on the classification proposed by the Xcc genome group http://genoma4.fcav.unesp.br/xanthomonas, the mutated genes belong to several categories: seven participate in intermediary metabolism; three are classified in the biosynthesis of small molecules; three are involved in macromolecule metabolism; two are cell structure constit- uents; four participate in another cellular process; two are related to mobile genetic elements; four are involved with pathogenicity, virulence, and adaptation; eight are hypothetical ORFs; and two are undefined ORFs. Therefore, among the 44 mutants there are 35 distinct mutated ORFs [see Additional file 1]. To verify that transposon insertion was random, one Southern blot analysis was evaluated. It was possible to estimate that the number of Xcc clones with double inserts in their genomes was approximately 6 in every 96 mutants of the library (Fig. 1). The same analysis was done on all 44 mutants and none of them had double inserts.

\section{Analysis of the growth curve in planta and in vitro}

To analyze the behavior of some mutants in terms of growth in vitro and in planta, 16 mutants were randomly

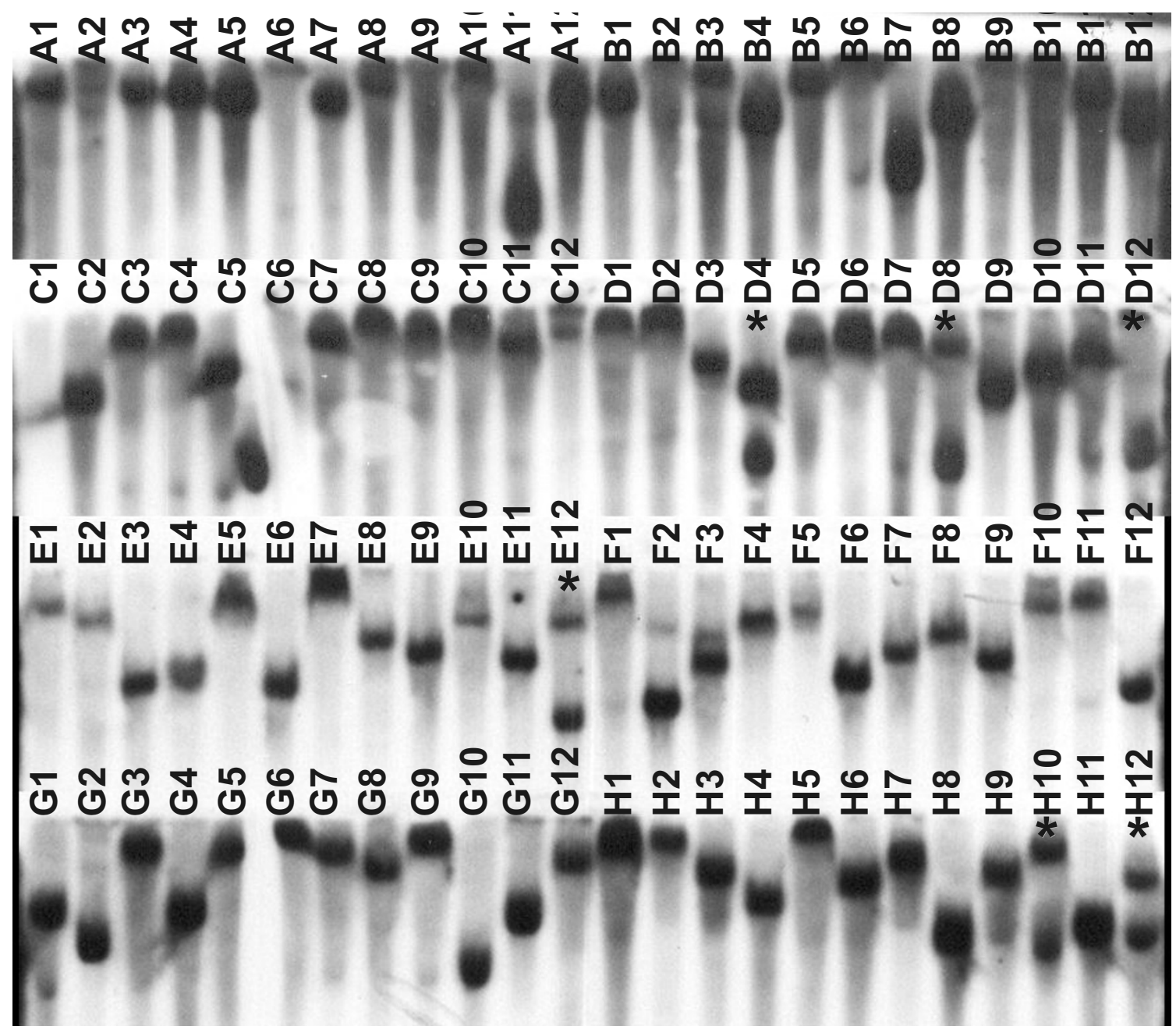

Figure I

Southern blot analysis shows transposon isertion. X-ray film image after exposure to DNA of Xanthomonas citri subsp. citri strain 306 isolated mutant clones, previously cleaved with Eco RI and hybridized with the sequence of the transposon Tn5 labeled with the AlkPhos Direct RPN 3680 kit (Amersham Biosciences). Mutants with a double insert are marked with an asterisk. 

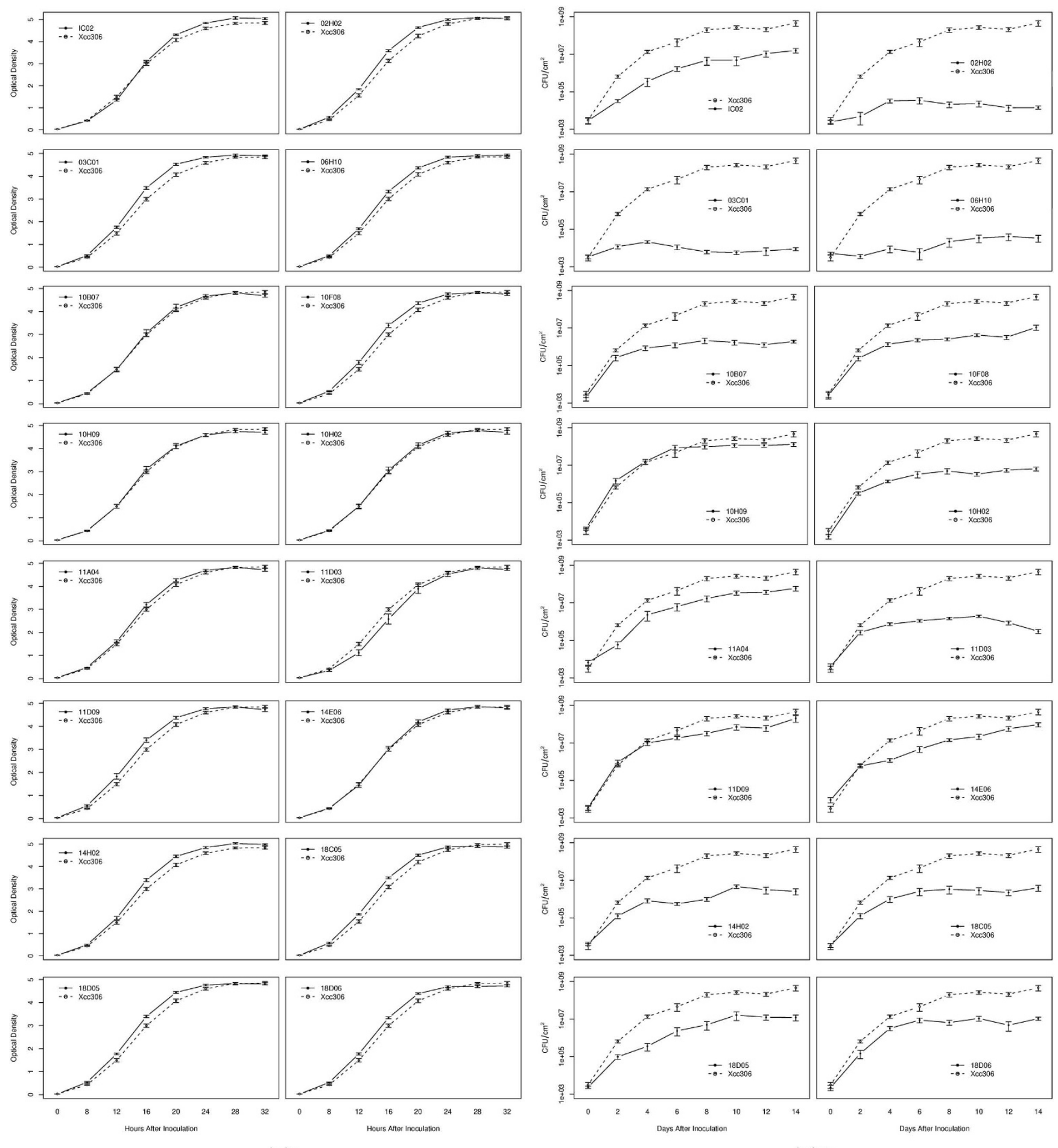

Figure 2

Xcc growth curves. Growth curves of 16 Xanthomonas citri subsp. citri mutants and wild type (Xcc strain 306) in vitro (left) and in citrus leaves (right). 
selected and analyzed together with the wild type (Xcc strain 306) (Fig. 2). Although all mutants were inoculated with the same number of cells, including the wild-type strain, we observed cellular concentration differences after 2 days of growth in citrus leaves. Wild type showed cell growth until 2 days, and from that point the growth curve in planta remained constant at close to $10^{10} \mathrm{cells} / \mathrm{cm}^{2}$ of leaf area. It was possible to group the 16 mutants into five distinct patterns based on the numbers of cells per square $\mathrm{cm}: 1)$ mutants that showed a low concentration $\left(10^{4}\right.$ $\left.10^{5}\right)$ of cells during the infection period $(03 \mathrm{C} 01,02 \mathrm{H02}$, $06 \mathrm{H} 10)$; 2) mutants that showed an average concentration $\left(10^{6}-10^{7}\right)$ of cells during the infection period (10B07, 10F08, 10H02, 18C05, IC02, 18D05, 18D06); 3) mutants that had high concentrations $\left(10^{7}-10^{8}\right)$ of cells during the cellular infection period $(10 \mathrm{H} 09,11 \mathrm{~A} 04$, 11D09, 14E06); 4) mutants that showed a sigmoid pattern of cell concentration around $10^{6}(14 \mathrm{HO} 2)$; and 5) mutants that had an increase in cell number equal to the wild type until the second day and then the concentration was stable $\left(10^{6}\right)$ until the 10th day, when it started to fall, reaching close to $10^{5}$ on the last day (11D03). Furthermore, the mutant 18D06 also presented a sigmoid growth curve, but with a cell concentration above $10^{6}$.
When the same mutants were grown in culture media, it was observed that the cells grew more similarly to the wild type over time. However, among all mutants tested, the 02H02 and 03C01 mutants, which in planta had lower cell concentrations (probably due to the presence of some toxic metabolite or repressor of the adaptative process that affected multiplication and growth capacity), did not cause any symptoms [see Additional file 1]. Intriguingly, both genes are identified as involved with the type III secretion system (TTSS), reinforcing its importance in the disease induction process.

\section{Gene expression}

To show that the mutated genes are related to the altered symptoms of disease and were involved in pathogenesis (with expression dependent on plant-pathogen interaction), the expression of 11 ORFs was analyzed through nucleic acid hybridization to labeled cDNA probes in two situations: cells multiplied in culture medium (in vitro) and cells multiplied in citrus leaves (in planta) (Fig. 3).

The results indicated that the ORFs XAC0102, XAC1495, XAC2053, XAC3263, XAC3285, XAC0340, XAC0095, XAC1927, XAC2047 and XAC3225 are only expressed

\section{CULTURE MEDIUM}

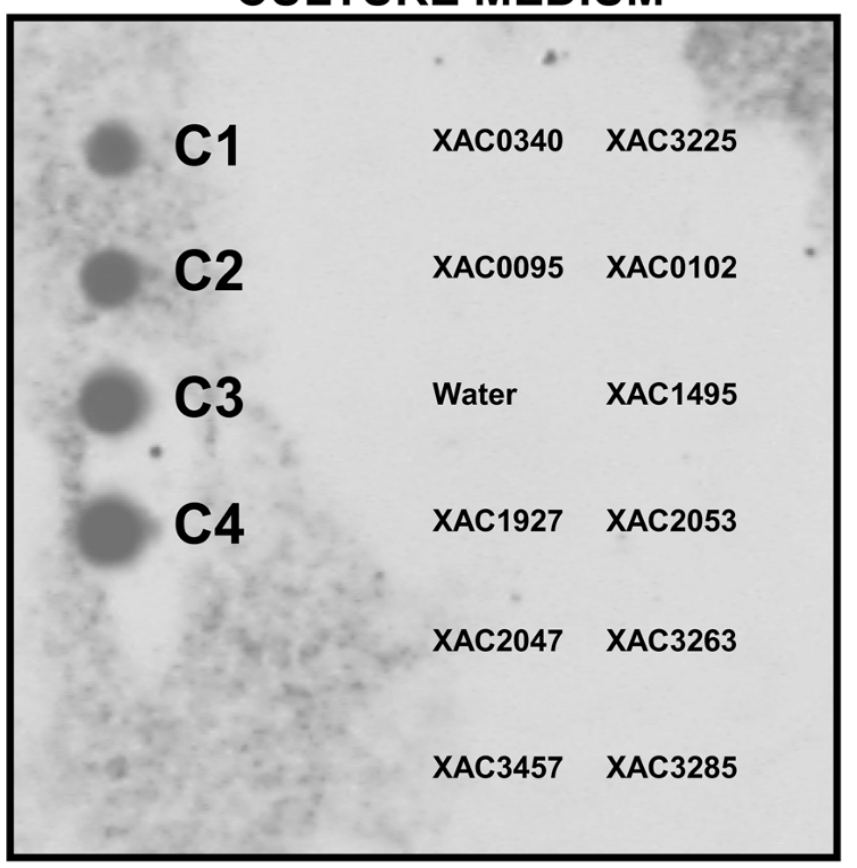

CITRUS LEAVES

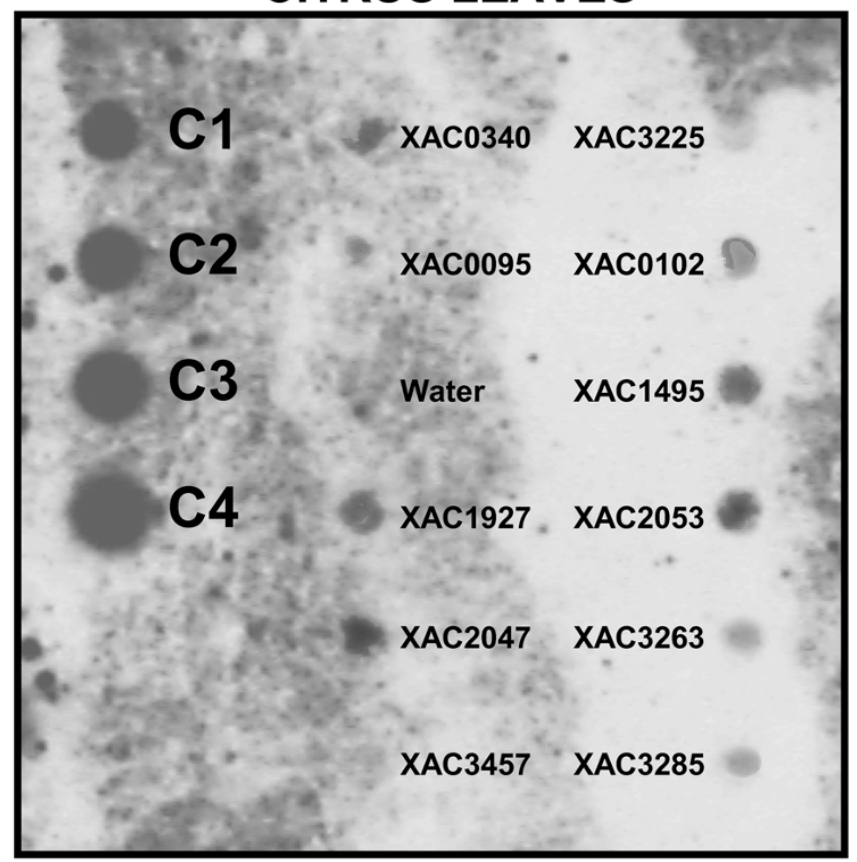

\section{Figure 3}

Nucleic acid hybridization using labeled cDNA probes. Nucleic acid hybridization using labeled cDNA probe to I I Xanthomonas citri subsp. citri strain 306 (Xcc) genes identified as important for pathogenicity through random mutagenesis. Panel $A$ = gene expression of ORFs when Xcc was multiplied in culture medium. Panel $B=$ gene expression of ORFs when Xcc was multiplied in citrus leaves for 3 days. $\mathrm{Cl}-\mathrm{C} 4=$ controls $(5 \mathrm{ng}, 20 \mathrm{ng}, 80 \mathrm{ng}$ and $320 \mathrm{ng}$, respectively). 
when Xcc is multiplied in vivo; it was not possible to identify expression of these ORFs when cells were multiplied in vitro. A single ORF, XAC3457, showed no significant expression in any of the conditions (in vitro and in vivo) (Fig. 3). The two experimental replications showed similar results.

\section{Discussion}

Random mutagenesis through random transposon insertion in vivo in the genome has been widely and successfully used to study several microorganisms, whether pathogens or not [8-11]. Using this technique for pathogenicity and virulence studies of the causal agent of the citrus canker, a library with approximately 10,000 viable mutants of $X$. citri subsp. citri isolate 306 was obtained. Through this strategy, the transposon/transposase complex was inserted directly into the cells through electroporation. Southern blot analysis showed that $6.25 \%$ (6 in 96) had a double transposon insertion, which is near that expected from the description accompanying the kit used to obtain mutants, where the rate of double inserts is about $1 \%$ of the clones (Epicentre Technologies).

After individual inoculation of 3,300 mutants in Rangpur lime (Citrus limonia) leaves, 44 mutants were identified with some alteration in their ability to induce citrus canker symptoms. The mutated ORFs in mutants with altered pathogenicity were identified through DNA sequencing.

In this group of mutants there were genes belonging to several functional categories, including genes previously known as being involved in the pathogenesis process, such as the proteins $\mathrm{HrpB} 4$ and UptC and new genes XAC0340, XAC4040 and XAC2047. The symptoms caused by these mutants were also widely variable, and eight of them did not cause disease, which was confirmed by the total absence of symptoms [see Additional file 1].

In addition, to show that the mutated genes were really involved in the pathogenesis process (in other words, their expression was dependent on the plant-pathogen interaction), the expression of 11 ORFs was analyzed through nucleic acid hybridization using labeled cDNA probes in two situations: cells multiplied in culture medium (in vitro) and cells multiplied in citrus leaves (in vivo) (Fig. 3). The analyses of the blots showed that among these genes it was possible to observe the expression of most in planta, which denotes their importance in interaction or adaptation events during the infection process.

However, no $p$ thA mutant was identified, despite Xcc having four distinct copies of $p t h A$, two in each plasmid. It could be that mutation of just one pthA gene does not affect the establishment of Xcc in either pathogenicity or symptoms. Swarup and coworkers [12] have shown that mutation in the pthA gene resulted in a complete loss of virulence on citrus, but the amino acid sequence coded by pthA [13] is distinct from all four pthA copies present in Xcc 306 [4]. We used homologous recombination to disrupt each copy of Xcc pthA in order to determine the contribution of each copy to pathogenicity and virulence.

However, this process is not trivial, because we would first have to obtain a null pthA mutant, ie, a mutant with all four copies of this gene mutated. Under these conditions the adaptability of the null mutant could be tested, and, using that mutant, the contribution of each copy of $p t h A$ could be evaluated. Another circumstance that may have influenced the absence of identified pthAs mutants is the probability of having all the Xcc genes mutated in our mutant library, which was only $47 \%$, whereas empirically, it is much easier to hit the main chromosome, due to its size, than the plasmids. So, the probability of mutating a gene in the plasmid is also very small in relation to the probability of mutating a gene on the main chromosome.

Two of the non-virulent mutants carry genes previously described as being necessary for pathogenicity, $h r p B 4$ (XAC0410) and hrpXct (XAC1266); these two genes are part of the $h r p$ (hypersensitive reaction and pathogenicity) system, which is present in most Gram-negative phytopathogenic bacteria, except for Agrobacterium, and is part of the TTSS [14]. Many results indirectly suggest that virulence proteins, also called virulence effectors, are injected by the pathogen directly inside the host cells through a pilus [15]. It is presumed that the effectual proteins stimulate or suppress several cellular functions of the host to benefit pathogen infection [16]. In X. campestris pv. vesicatoria $(\mathrm{Xcv})$, the $h r p$ cluster is $23 \mathrm{~kb}$ and contains six operons, $h r p A$ to $h r p F$ [17]. Two regulator genes, $h r p G$ and $h r p X$, located outside of the larger gene cluster, are responsible for activating the expression of $h r p$ genes in planta and in XVM2 synthetic culture media $[18,19]$. The mutant for hrpB4 in Xcv was not able to cause disease in susceptible pepper plants or the hypersensitive reaction (HR) in pepper plants carrying the respective compatible $R$ gene, in the presence of avr in the Xcv isolate used in the study [20]. Subsequent studies confirmed that this protein, HrpB4, was not secreted; in other words, it is a protein that acts in the bacterial cell. In the same study, HrpB4 remained in the soluble protein extract while AvrBs3 was secreted by the wild isolate, which was not observed in a hrpB4 defective mutant.

The gene hrpXv (hrpX of X. campestris pv. vesicatoria) was characterized and its function was determined. The amino acid sequence deduced indicated similarity with proteins of the AraC family, which act in the regulation of gene expression. Mutations at position 1,335 of that gene stopped the resulting mutant from inducing disease 
symptoms in susceptible pepper and tomato plants and HR in resistant plants. Complementation with fragments of that gene showed that only $580 \mathrm{bp}$ after the initiator codon is enough to produce a functional polypeptide. The cell concentration of $h r p X$ mutants in planta revealed that the mutant had $10^{5}$ times less bacteria than the wild type genotype [18].

These results described in previous studies of the genes $h r p B 4$ and $h r p X$ corroborate the results we obtained for the mutants $02 \mathrm{H} 02$ and 03C01, which carry mutations in the genes $h r p B 4$ and $h r p X c t$, respectively. These two mutants caused no disease and their growth in citrus leaves was much lower than the Xcc isolate 306 (Fig. 2). In Xcv, $\mathrm{HrpXv}$ acts as a transcriptional activator for genes of the group $h r p$. HrpXv is necessary for transcriptional activation of five $h r p$ genes (loci $h r p B$ to $h r p F$ ) [18]. The protein HrpB4 is necessary for the complete functionality of TTSS, since hrpB4 mutants are not able to secrete AvrBs3 or HrpB2 proteins in Xcv [20]. Therefore, it can be assumed that these two mutants, $02 \mathrm{H} 02$ and $03 \mathrm{C} 01$, lost their virulence because of their inability to take TTSS factors to the host cell, which are necessary for growth in planta, since when these mutants are reactivated in culture media, cellular multiplication is similar to that of wild type.

Another non-pathogenic mutant had mutated ORF XAC3980, which has similarity with the Xyllela fastidiosa gene htrA (high temperature requirement). First identified in $E$. coli, the locus htrA encodes a serine protease HtrA (also called DegP) that contains a catalytic triad (His ${ }_{105^{-}}$ Asp $_{135}-$ Ser $_{210}$ ) required for proteolytic activity and two PDZ domains responsible for oligomerization of the protein complex, substrate recognition and substrate binding. Besides proteolytic activity, E. coli HtrA shows chaperone activity in vitro at low temperatures, where a conformational change of the protein masks the proteolytic residues. At high temperatures, the catalytic residues are accessible and the proteolytic activity of HtrA prevails. The HtrA proteases identified in E. coli are required for growth at $42^{\circ} \mathrm{C}$ and for the degradation of abnormally folded proteins in the periplasm. It was later demonstrated that HtrA degrades heat-denatured proteins, in vivo and in vitro. The very small amount of substrate for HtrA catalytic activity found in vivo suggests that the main biological role of the protein is the removal of nonnative, abnormally folded proteins from inside the cellular envelope. In E. coli, HtrA is located in the periplasm, associated with the internal membrane [21-23].

Homologous HtrA proteins are found in most bacteria, and are well conserved throughout evolution. Their impact on bacterial physiology differs among the Gramnegative bacteria. In contrast to E. coli, HtrA is not essential for the growth of Salmonella enterica serovar Typhimu- rium at high temperatures, for instance. The htrA mutant of $S$. enterica serovar Typhimurium showed reduced virulence in a murine model and reduced survival in macrophages. The phenotypic characterization of htrA S. enterica serovar Typhimurium mutant revealed a decreased tolerance to oxidative stress, which can explain the reduced survival in macrophages, where reactive intermediates of oxygen are released during the oxidative explosion. htrA mutants of other Gram-negative pathogenic bacteria, such as Yersinia enterocolitica, Klebsiella pneumoniae and Brucella abortus, are sensitive to both high temperatures and oxidative stress [21]. Moreover, htrA mutants of Y. enterocolitica and of $B$. abortus show reduced virulence in murine models.

In Listeria monocytogenes, transcriptional analyses in an $h t r A$ mutant revealed that the gene $h t r A$ is not induced in response to thermal shock, but rather to stress caused by low $\mathrm{pH}$ and penicillin $\mathrm{G}$. In addition, a significant virulence decrease was detected in this mutant, revealing that HtrA is very important for the complete virulence of $L$. monocytogenes in mice. Recently, an htrA mutant of $L$. monocytogenes $10403 \mathrm{~S}$ was shown to be sensitive to oxidative stress and puromycin at high temperatures, and showed a reduced ability to produce biofilms and attenuated virulence in mice [24].

However, the attenuated virulence of Gram-negative htrA mutants remains unclear since they are more susceptible to stress than the isolated parent is; the mutants may also be less viable in host tissues, which will trigger several types of stress to the invading cell. Besides, it is believed that the chaperone and processing functions of HtrA protein are necessary for folding secreted proteins, or that HtrA may be involved in the oligomerization and exportation of virulence factors [22,23]. Therefore, the htrA gene has been shown to be essential for the complete virulence of many pathogens.

On the other hand, HtrA is not essential for bacterial growth under unstressed conditions, so it is a potential target for anti-pathogen drugs, including those that inhibit virulence rather than killing bacteria or stopping bacterial growth. It is assumed that anti-pathogen drugs reduce the pressure for development of resistance, which is an extremely important trait when it comes to agricultural pests, because such a drug must be applied over large areas and produces high selection pressure. Moreover, not killing the target makes this kind of drug type ecologically sustainable, because it cannot favor bacterial evolution [25-27]. Thus, the data in the literature and the results of the present study allow the assumption, for the first time, that the gene htrA (XAC3980) of Xcc is part of an important process during pathogenic colonization, being necessary for the complete virulence of the pathogen. 
Heme groups are responsible for carrying out a wide variety of biological functions in prokaryotes and eukaryotes. These groups are essential for respiration, oxygen metabolism and electron transport, as well as for prosthetic groups, hemoglobulins, hydroxylases, catalases, peroxidases and cytochromes [28]. More recently, new roles for heme groups have been described as biosensors of diatomic gases $[29,30]$ and modulators of protein activity [31]. Protoheme biosynthesis involves seven enzymatic steps, starting from the universal precursor delta-aminolevulinic acid (ALA). Other heme groups that cells need are obtained from protoheme modifications. In the step before production of protoheme, an iron ion $\left(\mathrm{Fe}^{2+}\right)$ is inserted in protoporphyrin IX, catalyzed by ferrochelatase [32].

One of the many roles played by protoheme in the cell is the constitution of cytochrome. Type c cytochromes, which contain a covalent heme c group, are widely distributed in organisms, in which they play a role in photosynthesis and electron transport from the respiratory chain. Most type c cytochromes of E. coli and S. enterica serovar Typhimurium are $\mathrm{c}_{552}$ cytochromes, which are comprised of six covalently bound heme groups and are located in the periplasmic space where they act as dissimilatory nitrite reductase [33].

Therefore, heme groups are used in basic metabolism for energy production, in the electron transport chain in an aerobic pathway, and in the nitrite reduction complex in an anaerobic pathway. The interruption of heme group production thus presumably affects the electron transport chain, which hinders the use of oxygen or nitrate as final electron recipients by cells. If this hypothesis is true, it explains why the mutant 11D09, which carries the interrupted ORF XAC4040, a delta-aminolevulinic dehydratase (hemB), does not cause disease and shows total absence of symptoms.

Proteomic analysis showed that proteins involved in glycolytic and related pathways and fermentation are overexpressed in hemB mutant cells, which show exponential growth, compared to the parental strain [34], indicating that the mutant hemB produces energy only from phosphorylation at the substrate level in vitro. Thus, the observation that the mutant 11D09 is multiplied in planta (Fig. 3 ) is explained by the use of carbon sources for the production of anaerobic ATP, or even by the use of the hemes produced by the plant.

So, considering the information available in the literature, the hemB mutant can survive in vitro and in planta by producing energy from hexoses or from intermediate compounds such as pyruvate, producing lactate, acetyl-CoA, producing ethanol, or L-arginine, producing $\mathrm{CO}_{2}+\mathrm{NH}_{4}$.
Moreover, its survival may also depend on the uptake of heme from the environment through specific carriers for this purpose present on Xcc, $C c m A, C c m B, C c m C$ and $c y c Z$ (XAC2323, XAC2324, XAC1679 and XAC2325, respectively). In the first three cases ATP production is low and for the latter the possibility of spending a lot of energy to transport the heme compound into the cell, which also results in a low ATP balance. So, in all cases, the cell would probably optimize energy expenditure for survival. Whereas the process of pathogenesis demands the production of various enzymes, proteins and other compounds, these observations suggest that these processes will not be realized because of their high energy consumption. Consequently, although the cell survives reasonably well, both in vitro and in planta, it will not develop the disease and thus no external symptoms will be observed. Finally, the fact that the mutant hemB had a growth curve in planta very similar to wild type may be an indication that it is performing aerobic metabolism due to internalization of heme compounds from the host and not causing the disease because the energy balance is not favourable, since transport through the membrane consumes so much energy.

Histidine kinases are proteins that can play a major process in bacterial metabolism. These proteins, together with their cognate response regulators (RR), can be part of two component systems (TCS), which constitute a signal transduction process in which bacteria sense, respond, and adapt to changes in their environment or intracellular state. Signal transduction starts when a histidine kinase senses a signal, e.g., by binding or reacting with a signaling molecule or due to a physical stimulus, and phosphorylates downstream proteins in the phosphorylation cascade that modulate the activity of a final set of protein targets, which then modulate protein activity or differential gene expression. Based on their components, two TCS exist: prototypical and phosphorelay systems [35].

In the phosphorelay TCS pathway, a stimulus activates autophosphorylation of a hybrid histidine kinase, namely, a histidine kinase containing a phospho-accepting receiver domain, typically at the C-terminal end of the protein. The catalytic and ATPase (HATPase - PF02518 Pfam A accession - http://pfam.sanger.ac.uk/help) domain of the histidine kinase is responsible for binding ATP and catalyzing autophosphorylation of a conserved histidine found within the dimerization and histidine phosphotransferase (HisKA - PF005121) domain. The HisKA domain mediates homodimerization and serves as the phosphodonor for a C-terminal receiver domain (response regulator - PF00072), similar to that found in response regulators. A histidine phosphotransferase (HPT - PF01627) then shuttles the phosphoryl group from the hybrid kinase to a soluble response regulator containing 
an output domain through protein-protein interaction or protein-DNA interactions leading to differential gene expression [36-38].

Xcc has a gene that codes for a histidine kinase, XAC3673, that is similar to the hybrid histidine kinase found in many TCS. XAC3673 has HisKA, HATPase, and response regulator domains [see Additional file 1]. An analysis using Psort [39] found that the predicted protein from XAC3673 is localized on the bacterial inner membrane and a blastp search result [40] found that the first 60 amino acids only match sequences from $X$. citri subsp. citri, X. campestris pv. vesicatoria and X. oryzae pv. oryzae, indicating that the $\mathrm{N}$-terminal sequence is exclusive to Xanthomonas. The blastp result from amino acids 200 to 578 at the C-terminus found similarities with RpfC protein from Xcc, and with many RpfC proteins that are involved in quorum sensing signaling mediated by a diffusible signal molecule DSF (diffusible signaling factor). This quorum sensing mechanism plays a key role in the regulation of xanthan (EPS) biosynthesis, gene expression, motility, adaptation, and bacterial virulence [41]. RpfC from Xcc (XAC1878) has the same three domains: HisKA, HATPase, and the response regulator, as well as an Hpt domain. Furthermore, RpfC is a bacterial inner membrane protein [42].

In Xanthomonas, the RpfC and RpfG proteins are a twocomponent system implicated in DSF perception and signal transduction. At a low cell density, the DSF sensor RpfC forms a complex with the DSF synthase RpfF through its receiver domain, which prevents the enzyme from effective synthesis of the DSF signal. In this step, DSF is synthesized at basal levels. But when the cell density increases, extracellular DSF increases, too. So at a high cell density, accumulated extracellular DSF interacts with $\mathrm{RpfC}$ and induces a conformational change in the sensor, which undergoes autophosphorylation and facilitates release of RpfF and phosphorelay from the sensor to its response regulator RpfG. Now, RpfF, together with RpfB, can induce the production of DSF, and RpfG can induce EPS biosynthesis, gene expression, motility, adaptation, and bacterial virulence [41].

The RpfC mutants produce significantly attenuated virulence factors, but synthesize about 16-fold higher DSF signal than the wild type $[42,43]$, whereas mutation of $r p f F$ or $r p f B$ abolishes DSF production and results in reduced virulence factor production $[44,45]$. Deletion of either $r p f C$ or $r p f G$ decreases the production of EPS and extracellular enzymes $[42,45]$. Based on these results, it was proposed that RpfC/RpfG is a signal transduction system that couples the synthesis of pathogenic factors to sensing of environmental signals that may include DSF itself [42].
Nevertheless, the current knowledge about the signal transduction pathway downstream of RpfC/RpfG is still little. Recent study presented evidence that the HD-GYP domain of RpfG is a cyclic di-GMP phosphodiesterase that degrades the second messenger bis-(3'-5')-cyclic dimeric guanosine monophosphate [46]. Furthermore, RpfG interacts with GGDEF domain-containing proteins [47]. The same authors, Andrade and coworkers, showed that RpfG interacts with sigma factor 54, NtrBC, and other regulatory proteins.

We found a mutant, 18D06, in our mutant library in which XAC3673 was knocked out; the mutation site is located inside the response regulator domain [see Additional file 1]. This mutant was observed at a high concentration in planta (Fig. 2) but with no symptom development [see Additional file 1]. Despite the ability of a hybrid histidine kinase to be involved in phosphorylation of any pathogenicity related gene, we believe that this protein plays a more sophisticated role in the virulence process in Xcc.

Considering the data presented above, namely a protein localized on the inner membrane with high similarity with RpfC, a Xanthomonas exclusive amino terminus, and high mutant cells concentration in planta, led us to propose this role for XAC3673 in Xcc: participation in the perception and transduction of signals in the quorum sensing system in this Xanthomonas citri subsp. citri. Besides these features, the fact that the response regulator domain (PF00072) from XAC3673 interacts with the domains CheB_methylest (PF01339), Response_reg (00072), Trans_reg_C (PF00486), GGDEF (00990), Hpt (PF01627), P2 (07194), Sigma54_activat (00158), and ANTAR (PF03861) [38] gave us more data on which to base this hypothesis.

XAC3673 protein can be on the inner membrane and the amino terminus could act as a sensor to perceive host or environmental signals. After signal reception, XAC3673 may be autophosphorylated. The HisKA domain serves as the phosphodonor for the C-terminal receiver domain (response regulator). A histidine phosphotransferase then shuttles the phosphoryl group from the hybrid kinase to a cytoplasmatic response regulator, which could be RpfG or another downstream protein in the signaling chain carrying at least one of the eight domains with which it could interact [38]. Thus, we are supposing that XAC3673 is an important required member of the signaling transduction process in Xcc (Fig. 4), acting together with RpfC/RpfG and required for complete virulence. When RpfC, RpfG or $\mathrm{XAC} 3673$ is not functional, virulence is abolished, but the mutant is viable. Another observation that we think is important is the site of the mutation on XAC3673: the response regulator domain. The response regulator 

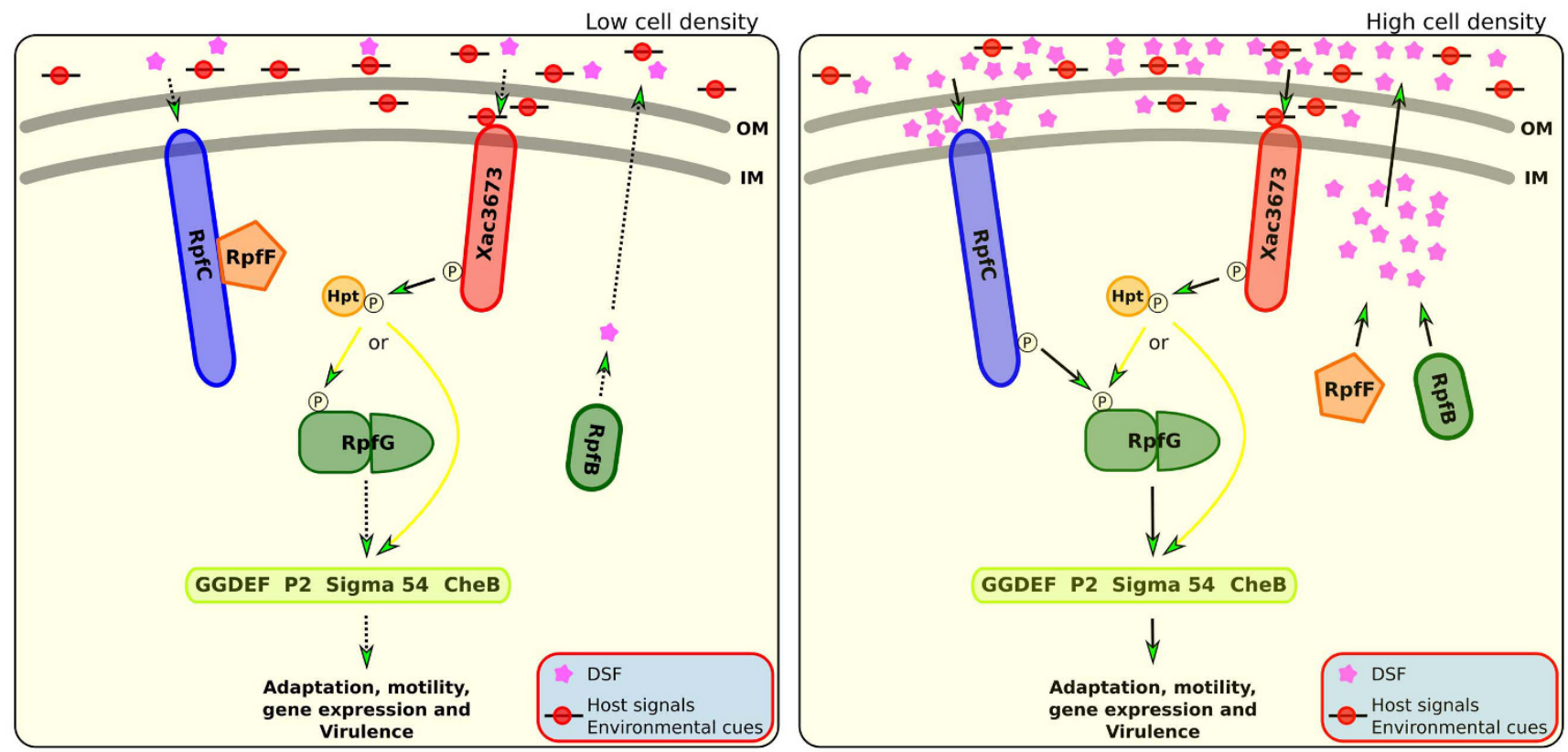

\section{Figure 4}

Schematic representation of a suggested DSF signaling model including XAC3673. Schematic representation of a suggested DSF signaling model including XAC3673. At a low cell density, the DSF sensor RpfC forms a complex with the DSF synthase RpfF, which prevents the effective synthesis of the DSF signal. At a high cell density, accumulated extracellular DSF signal interacts with RpfC, which undergoes autophosphorylation and facilitates release of RpfF and phosphorelay from the sensor to its response regulator RpfG. The event boosts DSF biosynthesis and induces the expression of the EPS and extracelular enzymes. In either, low or high cell density, there may be other stimuli (signals), in the extracellular environment from the host or the environment, regardless of the bacterial cellular concentration. The synthesis of Xcc virulence factors only start after the perception of such signals. XAC3673, through a phosphorylation cascade, relays this information to RpfG or to another protein downstream (arrows with yellow lines). A mutation in XAC3673 prevents the transduction of signals from the environment or host, and thus, the virulence factors are not produced, even in the presence of all functional $r p f$ genes and with a high cell concentration. The solid arrow indicates signal flow or signal generation and the dashed arrow indicates basal signal generation or no signal flow. OM = outer membrane; $I M=$ inner membrane.

domain in RpfC and XAC3673 are very similar, indicating that they could share the same protein-protein interactions with RpfG or with other proteins in the downstream signaling pathway. Figure 4 summarizes our hypothesis about the proposed role of XAC3673 in quorum sensing in Xcc.

Finally, we compared the Xcc genomic regions in which the mutated ORFs are located to other bacterial genomes. Basically, we used the sequence analysis tool BLAST [40] to compare these Xcc regions with the corresponding regions of the genomes of five other Xanthomonas species: $X$. campestris pv. vesicatoria, $X$. oryzae pv. oryzae MAFF, $X$. oryzae pv. oryzae KACC10331, X. campestris pv. campestris ATCC 33913 and X. campestris pv. campestris 8004. At the end of this comparative analysis, five regions were highlighted (Fig. 5). Region 1 (delimited by ORFs XAC1911 and XAC1929) and region 4 (delimited by ORFs XAC3260 and XAC3298), which hold respective knockout ORFs XAC1927, and XAC3263, XAC3285 and
XAC3294, are exclusive to Xcc. However, regions 2, 3 and 5, which contain respective knockout ORFs XAC2639, XAC3225 and XAC3320, are present in at least one of the other studied genomes, but not in all (Fig. 5). In addition, some characteristics of these regions, such as abnormal variation in nucleotide composition (GC percent, dinucleotides, codon usage) and the appearance of relaxases, mobilization proteins, phages, transposons and integrases (Fig. 5), are good indicators of viable lateral transfer regions [48]. Indeed, recently Lima and coworkers [49], when examining the Xcc genome in search of viable Xcc genomic region candidates for lateral transfer regions, also concluded that regions 2 and 5 (regions 20 and 23 respectively [49]) are genomic islands, which supports the hypothesis. The other three regions, 1, 3 and 4 (Fig. 5), have no corresponding sequences or regions in the work of these authors, but regions 3 and 4 are very similar to the XAUC12 and XAUC13 regions identified by Moreira and coworkers [50]. 

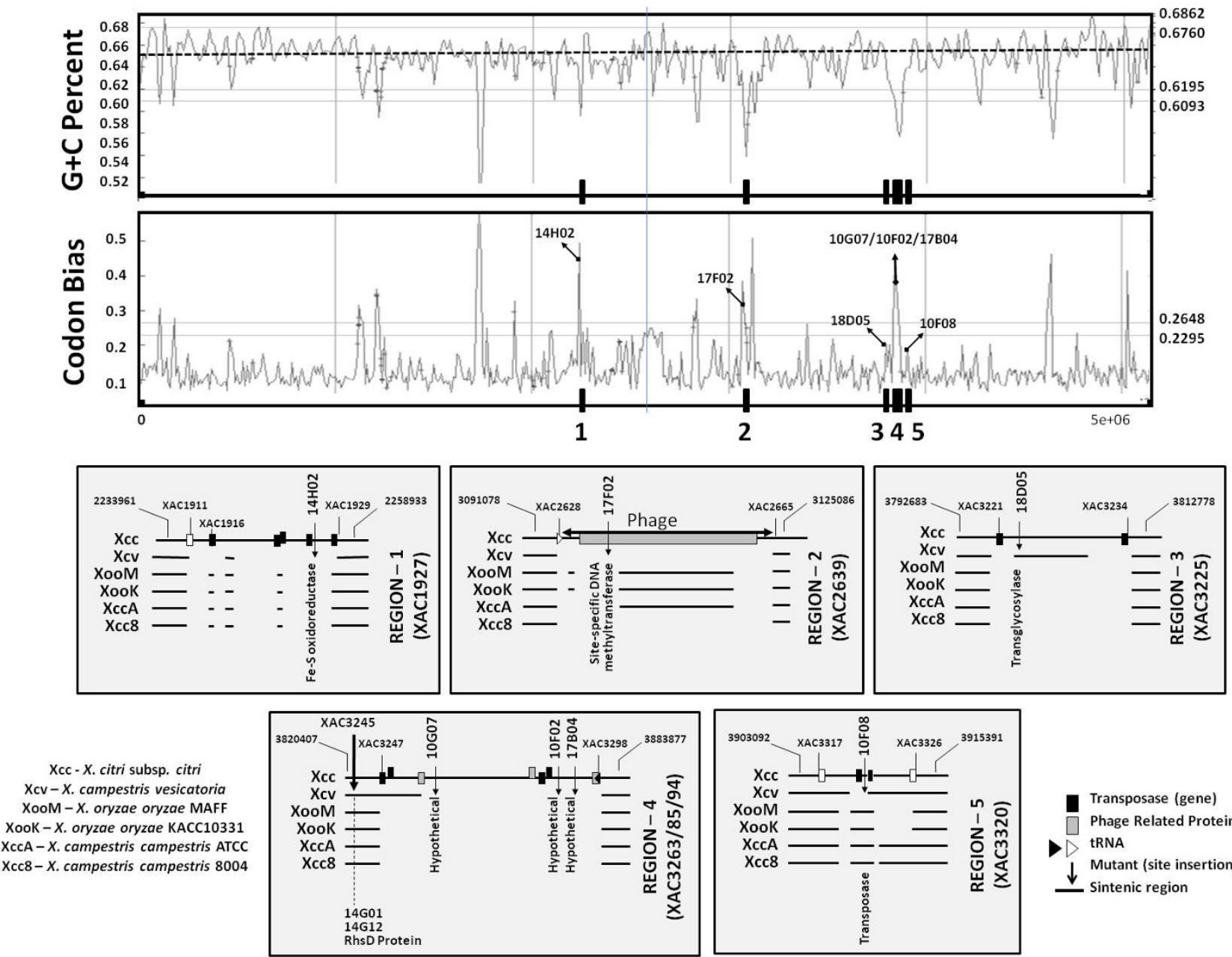

\section{Figure 5}

Xcc genome exclusive regions. Determination of possible Xcc exclusive regions on the basis of analysis of mutant (upstream and downstream) flanking regions. Five regions were found (I-5), three very close to each other (3-5). Notice that all regions have a GC content and codon bias sequence that differs from the rest of the genome profile. Details of each region are shown. Note that regions I and 4 are Xcc exclusive regions.

Being exclusive to Xcc, regions 1 and 4 deserve special attention (Fig. 5). The XAC3263, XAC3285 and XAC3294 ORFs, which encode hypothetical proteins of unknown roles and that showed different expression patterns under the conditions mentioned above, are in region 4 . This region is found in the ORF XAC3260 (plasmid mobilization protein) and extends until XAC3298 (one integrase downstream of a tRNA $\mathrm{Gly}_{\mathrm{l}}$ ), totaling $37.546 \mathrm{~kb}$. In terms of composition, this region has mainly hypothetical ORFs. The encoded product of one of these ORFs (XAC3266) interacts with the protein VirD4, a gene classically correlated with the type IV secretion system [51]. It is important to emphasize that upstream of this region there are ORFs that encode a virulence regulator (xrvA) (XAC3256), transposases (XAC3247) and regulated component colSR
(XAC3249/50). Most curious is the ORF XAC3245, which encodes an rhsD protein, and the respective mutants also show massive reduction of the necrosis phenotype (mutants 14G01 and 14G12), which also was upstream of region 4 (Fig. 5). In addition, for ORFs XAC3263, XAC3285 and XAC3294, no classically described domain was found in the probable proteins encoded by these hypothetical ORFs and an analysis by Psort [39] revealed that they are cytoplasmic proteins and, in a similar manner, no clusters of orthologous groups (COGs) of proteins [52] were found, demonstrating that there is no similarity with any other sequences.

In a different way, region 1 also calls attention by containing 5 transposases, alternating with hypothetical ORFs 
(Fig. 5). Among ORFs with functions previously predicted by genome annotations, there is ORF XAC1927, which encodes an $\mathrm{Fe}-\mathrm{S}$ oxidoreductase that has been knocked out, and another that encodes a hemolysin related protein (XAC1918). For this ORF, XAC1918, it has also been proven experimentally that its product is connected to the virD4 product [51]. Related to the structural aspect, this region, besides having abnormal variations in the constitution of its nucleotides, is located between two major conserved gene clusters related to flagellum biosynthesis and regulation. In other organisms, including some Xanthomonas, these genes are concatenated, evidence that reinforces the hypothesis that this region was acquired by a lateral transfer process.

Because of all of these peculiarities, these five regions qualify as strong candidates for classification as probable lateral transfer islands and, in this particular case, as probable pathogenicity islands, as they present many of the typical characteristics found in these regions [6].

Finally, another three ORFs were analyzed under this profile (data not shown): ORF XAC2639, which encodes a site-specific DNA methyltransferase, is inserted in a region that is characterized as a phage insertion region; the sequence is partially found only in the two sequenced species of X. oryzae and in X. campestris ATCC 33913; ORF $\mathrm{XAC} 3225$, which is in a region only found in X. vesicatoria; and ORF XAC3320, which encodes one transposase only absent in the $X$. vesicatoria strain.

In short, three of the seven ORFs described as candidate genes to be present in lateral transfer islands were analyzed in terms of expression levels and conditions. It was observed that they play important roles in plant-pathogen interrelations, because they are only expressed when cells are multiplied in planta. The culture medium does not contain compounds present in plants, and for this reason, it did not induce expression. However, the observation that mutants for these genes showed reduced virulence and symptom alterations supports their importance in the interaction with the host.

These results corroborate the altered pathogenicity of the mutants studied here when inoculated in a host plant, indicating that the products of these genes are important for pathogen establishment and development in the host.

\section{Conclusion}

The experiments described in the present study represent the first attempt to use a high-throughput mutagenesis analysis method to identify a wealth of genes that contribute to Xcc virulence. These results allowed identification of new putative virulence factors, as well as novel poten- tial targets for drugs in this strain, especially the genes present in the Xcc exclusive putative pathogenicity island.

\section{Methods}

\section{Bacterial strains, culture media and growth conditions}

Xcc strain 306 [4] was maintained in phosphate buffer at room temperature during all experiments. Growth experiments were performed in either TSA medium ( $10 \mathrm{~g} / \mathrm{L}$ tryptone, $10 \mathrm{~g} / \mathrm{L}$ sucrose, $1 \mathrm{~g} / \mathrm{L}$ sodium glutamate) or $\mathrm{NB}$ medium ( $3 \mathrm{~g} / \mathrm{L}$ beef extract, $5 \mathrm{~g} / \mathrm{L}$ peptone) at $28^{\circ} \mathrm{C}$, with addition of agar $(15 \mathrm{~g} / \mathrm{L})$ where solid medium was required. Cells were grown in test tubes containing $3 \mathrm{~mL}$ of culture medium, at $28^{\circ} \mathrm{C}$ with shaking at $200 \mathrm{rpm}$, or in Petri dishes in an incubator at $28^{\circ} \mathrm{C}$. When required, kanamycin or ampicillin was added to the culture medium to a final concentration of $100 \mathrm{~g} / \mathrm{mL}$. E. coli strain $\mathrm{DH} 10 \mathrm{~B}$ was maintained at $-80^{\circ} \mathrm{C}$ on Luria-Bertani (LB) medium containing $12.5 \%(\mathrm{v} / \mathrm{v})$ glycerol and was grown on $\mathrm{LB}$ medium at $37^{\circ} \mathrm{C}$ with shaking at $200 \mathrm{rpm}$.

\section{In vitro mutagenesis}

A set of Xcc strain 306 mutants was obtained by random insertion of the Tn5 transposon. The transposon was inserted by electroporation $(2500 \mathrm{~V}, 25 \mathrm{~F}, 200 \mathrm{ohms}, 0.2$ cm cuvette width) with an EZ::Tn5 KAN-2 Tnp Transposome Kit, according to the instructions of the manufacturer (Epicentre Technologies). Transformed colonies were selected on TSA culture medium containing kanamycin (transposon selection marker) and mutants were picked and transferred individually to 96-well microtitre plates containing TSA culture medium with kanamycin and $20 \%(\mathrm{v} / \mathrm{v})$ glycerol. After growing for 2 days at $28^{\circ} \mathrm{C}$ with shaking at $200 \mathrm{rpm}$, the plates were stored at $-80^{\circ} \mathrm{C}$.

\section{In vivo virulence test}

Mutants were individually multiplied in solid TSA medium with kanamycin under the conditions previously described. In each 14-cm Petri dish containing solid culture medium, it was possible to multiply 96 mutants by using a 96-pin replicator. After growth for $72 \mathrm{~h}$, each mutant was individually collected from the plate and placed into $1.5 \mathrm{~mL}$ polypropylene tube. The cellular concentration was adjusted by the addition of double-distilled water to an optical density of 0.3 at $600 \mathrm{~nm}$, which is equivalent to approximately $10^{8} \mathrm{CFU} / \mathrm{mL}$. The bacterial suspension was then infiltrated using a syringe to two points of the left abaxial side of young Rangpur lime leaves, which were used as host for the in vivo pathogenicity tests. The wild-type strain, used as a positive control, was inoculated on the right side of the same leaf using the same concentration and conditions. After inoculation, plants were grown in a chamber at $28^{\circ} \mathrm{C}$ with artificial light. The development of citrus canker symptoms in host plants was evaluated every day, from the $3^{\text {rd }}$ to the $21^{\text {st }}$ day after inoculation. Mutants that showed different symp- 
toms or levels of virulence from the wild-type strain were selected in this first screening. Each mutant selected was re-inoculated three times to confirm the results. All the symptoms were registered by digital photographs, including the ones presented by the wild-type strain.

\section{Total DNA extraction from Xanthomonas citri subsp. citri}

Mutant clones were multiplied in 96-well microtitre plates containing $1 \mathrm{~mL}$ of TSA culture medium and kanamycin for $48 \mathrm{~h}$ at $28^{\circ} \mathrm{C}$ and $200 \mathrm{rpm}$. Plates were then centrifuged for $30 \mathrm{~min}$ at 3,000 $\mathrm{g}$ at room temperature. The supernatant was discarded and $500 \mathrm{~L}$ of freshly prepared washing buffer (10.0 mM Tris- $\mathrm{HCl}$ pH 8.8, $3.0 \mathrm{mM}$ $\mathrm{KCl}, 1.25 \mathrm{mM} \mathrm{NaCl}$ ) was added to the cell pellet of each well. The cell pellet was resuspended by strong vortex agitation and centrifuged at 3,000 $\mathrm{g}$ for $15 \mathrm{~min}$ at room temperature. The washing step was repeated and the pellet was then resuspended by strong vortex agitation in $500 \mathrm{~L}$ of buffer D (25 mM sodium citrate, pH 7.0, 5.0 g/L Sarcosyl, $4 \mathrm{M}$ guanidine isothiocyanate) and kept in a water bath at $65^{\circ} \mathrm{C}$ for $1 \mathrm{~h}$. After cell lysis, $210 \mathrm{~L}$ of buffer P (667 $\mathrm{mM}$ Tris-HCl (pH 7.5), $833 \mathrm{mM} \mathrm{NaCl}, 83 \mathrm{mM}$ EDTA (pH 8.0)) was added to each well and the plates were agitated and centrifuged at 3,000 $\mathrm{g}$ for $30 \mathrm{~min}$ at room temperature. A 550- L aliquot of the supernatant was transferred to new 96-well microtitre plates and centrifuged at 3,000 g for $15 \mathrm{~min}$ at room temperature. After this procedure, 150 L of the supernatant was carefully transferred to a 96-well ELISA plate, avoiding transfer of pellet debris. To isolate DNA from the solution, 130 L of cold isopropanol ($20^{\circ} \mathrm{C}$ ) was added to each sample, which was then kept at $-20^{\circ} \mathrm{C}$ for $12 \mathrm{~h}$. The plates were centrifuged at 3,000 $\mathrm{g}$ for $45 \mathrm{~min}$ at $4^{\circ} \mathrm{C}$ and washed twice with $200 \mathrm{~L}$ of $70 \%$ ethanol, with the plates being centrifuged at 3,000 $g$ for 20 min at $4^{\circ} \mathrm{C}$ after each wash. The pellets were dried, resuspended in $40 \mathrm{~L}$ of TE buffer (10 mM Tris-HCl, pH 8.0, 0.1 mM EDTA) containing $1 \mathrm{~g} / \mathrm{mL}$ of RNase A and kept for 1 $\mathrm{h}$ at $37^{\circ} \mathrm{C}$. DNA quality and concentration were evaluated in a $0.8 \%$ agarose gel by comparing experimental samples with a known concentration of a high-quality DNA sample.

\section{Identification of mutated genes} DNA cleavage and fragment cloning

Total DNA from each Xcc mutant and from plasmid vector pBlueScript II SK DNA (Stratagene) was cleaved in a total volume of 25 L with Eco RI, Sac I or Sac II, as recommended by the enzyme manufacturer (New England Biolabs). These enzymes do not cut inside the transposon sequence and were used in pairs. After cleavage, the restriction enzymes were thermally inactivated and the fragments were cloned into the vector cleaved with the same enzyme pair combinations in a 500- L microcentrifuge tube containing $3.5 \mathrm{~L}$ of sterile double-distilled water, 1 L of $10 \times$ enzyme buffer, $0.5 \mathrm{~L}$ (200 U) of T4 DNA ligase, $2.0 \mathrm{~L}(15 \mathrm{~g})$ of total mutant DNA cleavage product and 3.0 L (5 g) of the vector cleavage reaction product. The ligation reaction was carried out at $16^{\circ} \mathrm{C}$ for $12 \mathrm{~h}$ and used to transform electrocompetent Escherichia coli DH10B cells [53]. This strategy yields clones containing the transposon flanked by the mutated gene.

\section{Transformation of Escherichia coli with the recombinant plasmid} An aliquot of the ligation reaction ( $2 \mathrm{~L}$ ) was added to 40 L of E. coli DH10B electrocompetent cells and electroporated as described before. Subsequently, the electroporated $E$. coli cells were transferred to a $15 \mathrm{~mL}$ screwcap polypropylene tube and $1 \mathrm{~mL}$ of SOC culture medium (20 $\mathrm{g} / \mathrm{L}$ tryptone, $5 \mathrm{~g} / \mathrm{L}$ yeast extract, $10 \mathrm{mM} \mathrm{NaCl}, 25 \mathrm{mM} \mathrm{KCl}$,

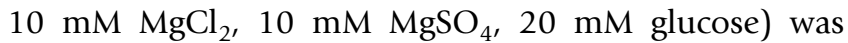
added to the tube. The cells were constantly shaken (200 $\mathrm{rpm}$ ) at $37^{\circ} \mathrm{C}$ for $1 \mathrm{~h}$. A 200- L aliquot was inoculated in a Petri dish containing LB culture medium with kanamycin, $100 \mathrm{mM}$ IPTG and $40 \mathrm{mg} / \mathrm{mL} \mathrm{X-Gal} \mathrm{[53].} \mathrm{After} \mathrm{growth}$ in an incubator for $12 \mathrm{~h}$ at $37^{\circ} \mathrm{C}$, three individual colonies of each mutant were picked and transferred to 96-well microtitre plates containing LB culture medium with kanamycin and grown for $12-14 \mathrm{~h}$ at $37^{\circ} \mathrm{C}$. Plasmids were extracted by an alkaline lysis method [53].

\section{Sequencing of mutated genes}

The extracted plasmid DNA was sequenced using BigDye terminator v3.0 (Applied Biosystems). To map the transposon insertion in each mutant, two independent sequencing reactions were performed, each using one of the oligonucleotides KAN-2 FP-1 or KAN-2 RP-1 (Epicentre Technologies). With this procedure, genome regions flanking the transposon were sequenced. The resulting sequences were analyzed by bioinformatics to remove possible transposon sequence, and aligned with the genome of $X$. citri subsp. citri isolate 306 to identify the mutated gene. Sequences were aligned through the algorithm BLASTn [40].

\section{Southern blotting}

Southern blotting was used to verify the rate of double insertions and randomness of transposition in the Xcc genome in our mutant library. A plate containing 96 mutants was randomly selected from the mutant library and total DNA was extracted as described above. DNA samples were cleaved with the restriction enzyme Eco RI and separated in a 1\% agarose gel in TBE buffer for $12 \mathrm{~h}$ at $35 \mathrm{~V}$. At the end of this process, the gel was stained with ethidium bromide and the image was documented. The DNA was transferred from the gel to a Hybond $\mathrm{N}^{+}$nylon membrane, following the manufacturer's instructions (Amersham Biosciences). Transposon Tn5 DNA (100 ng) was labeled using an AlkPhos Direct RPN 3680 labeling kit and probe signals were detected with a Gene Images 
CDP-Star RPN 3510 kit (Amersham Biosciences), according to the manufacturer's instructions. The membrane was finally exposed to X-ray film, stored at room temperature for $1 \mathrm{~h}$ and developed using the GBX kit (Kodak). The film was analyzed under a white light transilluminator. Two independent hybridizations were carried out to confirm results. The same mutants were independently multiplied and the process was fully repeated.

\section{Determination of Xanthomonas citri subsp. citri growth curves in planta}

Eight mutants with altered virulence $(02 \mathrm{H} 02,03 \mathrm{C} 01$, 06H10, 11D09, 18C05, 18D06, 11D03, 10H02) and a wild-type strain (isolate 306) were chosen for determination of growth curves in planta. These mutants carry knock-out versions of ORFs XAC0410, XAC1266, XAC0789, XAC4040, XAC0340, XAC3673, XAC1201 and XAC0095, respectively, created by transposon insertion. Mutant and wild-type strains were multiplied in TSA culture medium as above described. After growth, an aliquot of each was transferred to $1.5 \mathrm{~mL}$ microcentrifuge tubes containing $1 \mathrm{~mL}$ of sterile distilled water. After complete dissolution of the cell pellet, the concentration was adjusted to an OD of 0.1 at $600 \mathrm{~nm}$ then diluted to OD 0.01 (approximately $10^{4} \mathrm{CFU} / \mathrm{mL}$ ). Using a syringe, an orange leaf was infiltrated with each bacterial suspension. Quantitative analyses were performed 0, 2, 4, 6, 8 and 10 days after inoculation. The number of cells per leaf area was measured in three disks of $1 \mathrm{~cm}^{2}$ from each inoculated leaf. With a pestle, leaf disks were ground in $1 \mathrm{~mL}$ of double-distilled sterile water. Serial dilutions of $10^{-1}$ to $10^{-}$ ${ }^{7}$ were prepared and $10 \mathrm{~L}$ of each dilution was used to inoculate TSA culture medium containing kanamycin (except for the wild type) using a microculture technique [54]. Plates were kept at $28^{\circ} \mathrm{C}$ for 2 days, and isolated colonies (cells) were counted. The experiment was repeated independently three times.

\section{Gene expression analysis detected through nucleic acid hybridization using CDNA probes}

Bacterial cells were grown in a plate for $72 \mathrm{~h}$ under the above conditions. To obtain RNA from cells growing in the culture media, suspension of Xcc 306 cells was adjusted for OD 0.3 at $600 \mathrm{~nm}$, and $1 \mathrm{~mL}$ was inoculated in $50 \mathrm{~mL}$ liquid NA medium, then inoculated for $48 \mathrm{~h}$ in a shaker $(200 \mathrm{rpm})$ at $28^{\circ} \mathrm{C}$. Cells were transferred to 30 $\mathrm{mL}$ tubes and total RNA was extracted with TRIzol reagent (Invitrogen) as recommended by the manufacturer. Samples were treated with DNase I (Invitrogen) according to the manufacturer's instructions, and then stored at $-80^{\circ} \mathrm{C}$ until use. To obtain RNA from cells growing in the host, at least 20 citrus leaves were infiltrated with a suspension of Xcc 306 cells (OD 0.3, $600 \mathrm{~nm}$ ). At 3 days after inoculation, leaves were collected and minced in cold distilled water, in order to facilitate the exudation of bacterial cells to the liquid medium. After $10 \mathrm{~min}$ of agitation in an ice bath, the cut leaves were removed and bacterial cells were collected in a Corex tube by centrifuging at 5,000 $\times g$ for $10 \mathrm{~min}$. Total RNA extraction and DNase I treatment were perfomed as described above. Eleven primer pairs (Table 1) were designed for the amplification of the 11 Xcc ORFs for which some sort of virulence deficiency was detected after mutation. The amplification products were used in a nucleic acid hybridization using labeled cDNA probe technique as described below in order to assess possible differential gene expression in these mutants.

Xcc 306 DNA samples were used in PCR performed using an initial denaturing step of $94^{\circ} \mathrm{C}$ for $3 \mathrm{~min}$, followed by 35 cycles comprising a denaturing step of $94^{\circ} \mathrm{C}$ for $30 \mathrm{~s}$, an annealing step at $48^{\circ} \mathrm{C}$ for $30 \mathrm{~s}$, and a polymerization step at $72^{\circ} \mathrm{C}$ for $2 \mathrm{~min}$. A final polymerization step of $72^{\circ} \mathrm{C}$ for 4 min was run, and then samples were kept at $4{ }^{\circ} \mathrm{C}$ until use. The amplification reaction was carried out with $0.2 \mathrm{~L}$ of DNA, $5 \mathrm{~L}$ of $10 \times$ buffer, $1.0 \mathrm{~L}$ of $50 \mathrm{mM}$ $\mathrm{MgCl}_{2}, 1.0 \mathrm{~L}$ of $10 \mathrm{mM}$ dNTP, $2.5 \mathrm{~L}$ of each primer, 37.5

Table I: Primers used in nucleic acid hybridization. Primers and respective Xanthomonas citri subsp. citri ORFs employed in the amplification of ORFs used in nucleic acid hybridization using labeled cDNA probes.

\begin{tabular}{|c|c|c|c|c|}
\hline ID & ORF & Size (bp) & Forward Primer & Reverse Primer \\
\hline 1 & XAC0340 & 432 & gATACCCCATATgAATgCgAT & CAgCgCCAAgCTTATgCCATg \\
\hline 2 & XAC0095 & 222 & AggAgAgCCATATgCACgACg & TTgCATCgAATTCAgTgCgTT \\
\hline 3 & Water & & & \\
\hline 4 & XAC 1927 & 1.179 & ggAgTCTCATATgCTgACgCg & CCggTACCTCgAgTgTCATg \\
\hline 5 & XAC2047 & 1.224 & ggATgggCATATggCAAgCAg & AACggAgAATTCATgCCTgCg \\
\hline 6 & XAC3457 & 648 & CggCATTCATATgACTCССTT & CATCTgCggATCCACATTACT \\
\hline 7 & XAC3225 & 1.278 & TCgggTgTCATATgATCATgC & ATgCAgCCTCgAgCgTACATC \\
\hline 8 & $\mathrm{XACOI02}$ & 660 & ATCAgCTgCggCAACAggTg & AgCgggTCAgTCTgAAgACACg \\
\hline 9 & $\mathrm{XACl} 495$ & 405 & ATATCСТCATATgTCCAAATC & ATTTgACTCgAgACggATCAg \\
\hline 10 & XAC2053 & 2.361 & gTggTgCCTTACggTTTCAg & CAgATCAgCCCATTACgACg \\
\hline 11 & XAC3263 & 537 & AACCACATCgCTTTCTTCCC & TggATCgTTTgCTgACgg \\
\hline 12 & XAC3285 & 429 & ATggACTTCATgCACgACC & gAACTggAAACCTggATgAgC \\
\hline
\end{tabular}


L of sterile double-distilled water and 0.3 L of Taq DNA polymerase (Invitrogen). An aliquot (5 L) of the amplification product was electrophoresed in a $1 \%$ agarose gel, stained with ethidium bromide and visualized using an ultraviolet light transilluminator. The reaction was considered positive for a gene when the obtained product's size was as expected.

An aliquot of $400 \mathrm{ng}$ of the amplified PCR product was denatured by addition of one volume of $0.4 \mathrm{~N} \mathrm{NaOH}$ followed by heating at $70^{\circ} \mathrm{C}$ for $10 \mathrm{~min}$. The solution was put into an ice bath for $5 \mathrm{~min}$ and an equal volume of cold $2 \mathrm{M}$ ammonium acetate ( $\mathrm{pH} 7.0$ ) was added. Meanwhile, positively charged nylon membranes, previously equilibrated in $6 \times \operatorname{SSC}(0.9 \mathrm{M} \mathrm{NaCl}, 90 \mathrm{mM}$ sodium citrate) for $30 \mathrm{~min}$, were mounted in a Bio-Dot apparatus (Bio-Rad). To assure denaturation of DNA, $500 \mathrm{~L}$ of $0.4 \mathrm{~N} \mathrm{NaOH}$ was applied under vacuum to each well of the transfer apparatus. Denatured DNA samples representing ORFs of interest were then transferred under vacuum to the membrane. Samples were quickly washed in $2 \times$ SSC and the DNA was fixed with an ultraviolet crosslinker (Ultraviolet Crosslinker Model CL-1000, UVP), according to the membrane manufacturer's recommendations (Amersham Biosciences). The membrane was placed in a plastic bag, sealed and kept in a refrigerator until use.

Approximately $5 \mathrm{~g}$ of $X$. citri subsp. citri (isolate 306) total RNA, obtained from cells grown in culture medium or in planta and treated with DNase I, were used individually for the synthesis of first-strand cDNA with the SuperScript First-Strand synthesis system for RT-PCR (Invitrogen) according to the manufacturer's instructions. After synthesis of first-strand cDNA, $2 \mathrm{U}$ of RNase $\mathrm{H}$ was added to each sample. Samples were gently shaken, kept at $37^{\circ} \mathrm{C}$ for 20 min and then stored at $-20^{\circ} \mathrm{C}$ until use. The first-strand cDNA of each sample was labeled with alkaline phosphatase using the AlkPhos Direct Labeling kit (Amersham Biosciences). The membrane was pre-hybridized, hybridized and submitted to post-hybridization washes using the same kit, following the manufacturer's instructions. Detection was performed with CDP-Star (Amersham Biosciences) for $5 \mathrm{~min}$ at room temperature. After draining excess reagent, the membrane was exposed to X-ray film (Kodak) for $1 \mathrm{~h}$. The film was then developed and the image digitized with appropriate equipment. Two membranes were prepared for experiment replication. For one, cDNA obtained from cells grown in culture medium was hybridized first, followed by the cDNA obtained from cells grown under in planta conditions. In the other membrane, the opposite order of hybridization was performed: cDNA obtained from cells grown under in planta conditions was hybridized first, followed by cDNA obtained from cells grown in culture medium. In both situations, the probe was removed from the membrane using boiling
$0.1 \%$ SDS, and the membrane was kept in this solution during cooling to room temperature.

\section{Authors' contributions}

MLL, JD and JBB carried out in vitro mutagenesis, mutant library construction and in vivo virulence test. MLL and CBF carried out growth curves. MLL and JBB carried out Southern blotting experiments. MLL was responsible for customizing a protocol for and extracting the total DNA, identification of mutated genes, nucleic acid hybridization using labeled cDNA probes and general coordination of the study. MITF and JCFO coordinated and oversaw the project. JAF and ACRS conceived the project. MLL, LMM and JAF were responsible for most data interpretation and final manuscript elaboration. All authors read and approved the final manuscript.

\section{Additional material}

\section{Additional file 1}

Characterization of XCC mutants ${ }^{a}$. This table provides symptoms, ORF's identification code, gene's name, mutant's identification code, transposon insertion site, and functional category for the 44 mutants. Additionally, mutants with growth curves and gene expression are indicated.

Click here for file

[http://www.biomedcentral.com/content/supplementary/14712180-9-12-S1.pdf]

\section{Acknowledgements}

This work has been supported by Fundação de Amparo à Pesquisa do Estado de São Paulo (FAPESP) and by Fundo de Defesa da Citricultura (FUNDECITRUS). The first author is thankful to FAPESP through a PhD fellowship (process no. 02/I3862-6) for the development of this work. JCFO is recipient of a Jovem Pesquisador research grant from FAPESP (process no. 04/02006-7). This work is part of the PhD thesis of MLL. The authors thank Marta Tanrikulu of ScienceDocs.com for editing of an earlier version of this manuscript.

\section{References}

I. Schaad NW, Postnikova E, Lacy G, Sechler A, Agarkova I, Stromberg PE, Stromberg VK, Vidaver AK: Emended classification of xanthomonad pathogens on citrus. Systematic and Applied Microbiology 2006, 29(8):690-695.

2. Whiteside J, Garnsey S, Timmer L: Compendium of citrus diseases Saint Paul: APS Press; 1988.

3. Feichtenberger E: Manejo ecológico das principais doenças fúngicas e bacterianas dos citros no Brasil. In Anais do V Seminário Internacional de Citros - Tratos Culturais Edited by: Donadio L. Bebedouro: Fundação Cargill; 1998:517.

4. da Silva ACR, Ferro JA, Reinach FC, Farah CS, Furlan LR, Quaggio RB, Monteiro-Vitorello CB, Sluys MAV, Almeida NF, Alves LMC, do Amaral AM, Bertolini MC, Camargo LEA, Camarotte G, Cannavan F, Cardozo J, Chambergo F, Ciapina LP, Cicarelli RMB, Coutinho LL, Cursino-Santos JR, El-Dorry H, Faria JB, Ferreira AJS, Ferreira RCC, Ferro MIT, Formighieri EF, Franco MC, Greggio CC, Gruber A, Katsuyama AM, Kishi LT, Leite RP, Lemos EGM, Lemos MVF, Locali EC, Machado MA, Madeira AMBN, Martinez-Rossi NM, Martins EC, Meidanis J, Menck CFM, Miyaki CY, Moon DH, Moreira LM, Novo MTM, Okura VK, Oliveira MC, Oliveira VR, Pereira HA, Rossi A, Sena JAD, 
Silva C, de Souza RF, Spinola LAF, Takita MA, Tamura RE, Teixeira EC, Tezza RID, dos Santos MT, Truffi D, Tsai SM, White FF, Setubal JC, Kitajima JP: Comparison of the genomes of two Xanthomonas pathogens with differing host specificities. Nature 2002, 4I7(6887):459-463.

5. Goryshin IY, Jendrisak J, Hoffman LM, Meis R, Reznikoff WS: Insertional transposon mutagenesis by electroporation of released Tn 5 transposition complexes. Nature Biotechnology 2000, 18:97-100

6. Schmidt $\mathrm{H}$, Hensel M: Pathogenicity islands in bacterial pathogenesis. Clinical Microbiology Review 2004, 17: 14-56.

7. Krysan PJ, Young JC, Sussman MR: T-DNA as an insertional mutagen in Arabidopsis. Plant Cell 1999, I I ( I2):2283-2290.

8. Brown JS, Holden DW: Insertional mutagenesis of pathogenic fungi. Current Opinion in Microbiology I998, I (4):390-394(5).

9. de Jesus Ferreira MC, Bao X, Laizé V, Hohmann S: Transposon mutagenesis reveals novel loci affecting tolerance to salt stress and growth at low temperature. Current Genetics 200I, 40:27-39.

10. Hudson P, Gorton TS, Papazisi L, Cecchini K, Frasca S, Geary S]: Identification of a virulence-associated determinant, dihydrolipoamide dehydrogenase (Ipd), in Mycoplasma gallisepticum through in vivo screening of transposon mutants. Infection and Immunity 2006, 74(2):931-939.

II. Laasik E, Ojarand M, Pajunen M, Savilahti H, Mäe A: Novel mutants of Erwinia carotovora subsp. carotovora defective in the production of plant cell wall degrading enzymes generated by Mu transpososome-mediated insertion mutagenesis. FEMS Microbiology Letters 2005, 243:93-99.

12. Swarup S, De Feyter R, Brlansky RH, Gabriel DW: A pathogenicity locus from Xanthomonas citri enables strains from severa pathovars of $X$. campestris to elicit cankerlike lesions on citrus. Phytopathology 1991:802-809.

13. Yang Y, Gabriel DW: Intragenic recombination of a single plant pathogen gene provides a mechanism for the evolution of new host specificities. Journal of Bacteriology 1995 I77( I 7):4963-8.

14. Cornelis GR, Van Gijsegem F: Assembly and function of type III secretory systems. Annual Review of Microbiology 2000, 54:735-774.

15. Jin Q, He SY: Role of the Hrp pilus in type III protein secretion in Pseudomonas syringae. Science 2001, 294:2556-2558.

16. Staskawicz BJ, Mudgett MB, Dangl JL, Galan JE: Common and contrasting themes of plant and animal diseases. Science 200I, 292(5525):2285-2289.

17. Bonas U, Schulte R, Fenselau S, Minsavage GV, Staskawicz BJ: Isolation of a gene cluster from Xanthomonas campestris pv. vesicatoria that determines pathogenicity and the hypersensitive response on pepper and tomato. Molecular Plant-Microbe Interactions 1991, 4:81-88.

18. Wengelnik K, Bonas U: HrpXv, an AraC-type regulator, activates expression of five of the six loci in the hrp cluster of Xanthomonas campestris pv. vesicatoria. Journal of Bacteriology 1996, I 78( I 2):3462-3469.

19. Wengelnik K, Ackerveken G Van den, Bonas U: HrpG, a key hrp regulatory protein of Xanthomonas campestris pv. vesicatoria is homologous to two-component response regulators. Molecular Plant-Microbe Interactions 1996, 9:704-7/2

20. Rossier O, Ackerveken G van den, Bonas U: HrpB2 and HrpF from Xanthomonas are type III-secreted proteins and essential for pathogenicity and recognition by the host plant. Molecular Microbiology 2000, 38(4):828-838.

21. Kim DY, Kim KK: Structure and function of HtrA family proteins, the key players in protein quality control. Journal of Biochemistry and Molecular Biology 2005, 38(3):266-274.

22. Clausen T, Southan C, Ehrmann M: The HtrA family of proteases: implications for protein composition and cell fate. Molecular Cell 2002, 10(3):443-455.

23. Sassoon N, Arie JP, Betton JM: PDZ domains determine the native oligomeric structure of the DegP (HtrA) protease. Molecular Microbiology 1999, 33:583-589.

24. Wilson RL, Brown LL, Kirkwood-Watts D, Warren TK, Lund SA, King DS, Jones KF, Hruby DE: Listeria monocytogenes $10403 \mathrm{~S}$ HtrA is necessary for resistance to cellular stress and virulence. Infection and Immunity 2006, 74:765-768.
25. Otto M: Quorum-sensing control in Staphylococci - a target for antimicrobial drug therapy? FEMS Microbiology Letters 2004, 24I:|35-|4|

26. Cegelski L, Marshall GR, Eldridge GR, Hultgren S): The biology and future prospects of antivirulence therapies. Nature Reviews Microbiology 2008, 6:17-27.

27. Escaich S: Antivirulence as a new antibacterial approach for chemotherapy. Current Opinion in Chemical Biology 2008, I 2(4):400-408.

28. Hamza I, Chauhan S, Hassett R, O'Brian MR: The bacterial IRR protein is required for coordination of heme biosynthesis with iron availability. Journal of Biological Chemistry 1998, 273(34):21669-2I674

29. Gilles-Gonzalez MA, Ditta GS, Helinski DR: A haemoprotein with kinase activity encoded by the oxygen sensor of Rhizobium meliloti. Nature 199I, 350(63 I4): 170-172.

30. Verma A, Hirsch DJ, Glatt CE, Ronnett GV, Snyder SH: Carbon monoxide: a putative neural messenger. Science 1993 , 259(5093):38I-384

31. Lathrop JT, Timko MP: Regulation by heme of mitochondrial protein transport through a conserved amino acid motif. Science 1993, 259(5094):522-525.

32. Beale SI: Biosynthesis of Hemes. In Escherichia coli and Salmonella Cellular and Molecular Biology 2nd edition. Edited by: Neidhardt FC, III RC, Ingraham JL, Lin ECC, Low KB, Magasanik B, Reznikoff WS, Riley M, Schaechter M, Umbarger HE. Washington, DC: ASM Press; 1996:73|-748.

33. Kajie SI, Anraku Y: Purification of a hexaheme cytochrome $c_{552}$ from Escherichia coli $\mathrm{KI} 2$ and its properties as a nitrite reductase. European Journal of Biochemistry 1986, I 54:457-463.

34. Kohler C, von Eiff C, Peters G, Proctor RA, Hecker M, Engelmann S: Physiological characterization of a heme-deficient mutant of Staphylococcus aureus by a proteomic approach. Journal of Bacteriology 2003, 185:6928-6937.

35. Qian W, Han ZJ, He C: Two-component signal transduction systems of Xanthomonas spp.: a lesson from genomics. Molecular Plant-Microbe Interactions 2008, 21(2): I5|-16I.

36. Mascher T, Helmann JD, Unden G: Stimulus perception in bacterial signal-transducing histidine kinases. Microbiology and Molecular Biology Reviews 2006, 70(4):910-938.

37. Dow M: Diversification of the function of cell-to-cell signaling in regulation of virulence within plant pathogenic xanthomonads. Science Signaling 2008, I(2 I):pe23.

38. Finn RD, Tate J, Mistry J, Coggill PC, Sammut SJ, Hotz HR, Ceric G, Forslund K, Eddy SR, Sonnhammer ELL, Bateman A: The Pfam protein families database. Nucleic Acids Research 2008:D28I-D288.

39. Nakai K, Horton P: PSORT: a program for detecting sorting signals in proteins and predicting their subcellular localization. Trends in Biochemical Sciences 1999, 24:34-36.

40. Altschul SF, Madden TL, Schaffer AA, Zhang JH, Zhang Z, Miller W, Lipman DJ: Gapped BLAST and PSI-BLAST: a new generation of protein database search programs. Nucleic Acids Research 1997, 25(I 7):3389-3402.

4I. He YW, Zhang LH: Quorum sensing and virulence regulation in Xanthomonas campestris. FEMS Microbiology Reviews 2008, 32(5):842-857.

42. Slater H, Alvarez-Morales A, Barber CE, Daniels MJ, Dow JM: A twocomponent system involving an HD-GYP domain protein links cell-cell signalling to pathogenicity gene expression in Xanthomonas campestris. Molecular Microbiology 2000, 38(5):986-1003.

43. Wang LH, He Y, Gao Y, Wu JE, Dong YH, He C, Wang SX, Weng LX, Xu JL, Tay L, Fang RX, Zhang LH: A bacterial cell-cell communication signal with cross-kingdom structural analogues. Molecular Microbiology 2004, 5 I (3):903-9I2.

44. Barber CE, Tang JL, Feng JX, Pan MQ, Wilson TJ, Slater H, Dow JM, Williams $P$, Daniels $\mathrm{MJ}$ : A novel regulatory system required for pathogenicity of Xanthomonas campestris is mediated by a small diffusible signal molecule. Molecular Microbiology 1997, 24(3):555-566.

45. He YW, Xu M, Lin K, Ng YJA, Wen CM, Wang LH, Liu ZD, Zhang HB, Dong YH, Dow JM, Zhang LH: Genome scale analysis of diffusible signal factor regulon in Xanthomonas campestris pv. campestris: identification of novel cell-cell communicationdependent genes and functions. Molecular Microbiology 2006 , 59(2):610-622 
46. Ryan RP, Fouhy Y, Lucey JF, Crossman LC, Spiro S, He YW, Zhang LH, Heeb S, Cámara M, Williams P, Dow JM: Cell-cell signaling in Xanthomonas campestris involves an HD-GYP domain protein that functions in cyclic di-GMP turnover. Proceedings of the National Academy of Sciences of the United States of America 2006, 103(17):67|2-67|7.

47. Andrade MO, Alegria MC, Guzzo CR, Docena C, Rosa MCP, Ramos CHI, Farah CS: The HD-GYP domain of RpfG mediates a direct linkage between the Rpf quorum-sensing pathway and a subset of diguanylate cyclase proteins in the phytopathogen Xanthomonas axonopodis pv. citri. Molecular Microbiology 2006, 62(2):537-55।.

48. Koonin EV, Makarova KS, Aravind L: Horizontal gene transfer in prokaryotes: quantification and classification. Annual Review of Microbiology 2001, 55:709-742.

49. Lima WC, Sluys MAV, Menck CFM: Non-gamma-proteobacteria gene islands contribute to the Xanthomonas genome. OMICS 2005, 9(2): 160-I72.

50. Moreira LM, Souza RFD, Digiampietri LA, da Silva ACR, Setubal JC: Comparative analyses of Xanthomonas and Xylella complete genomes. OMICS 2005, 9:43-76.

51. Alegria MC, Souza DP, Andrade MO, Docena C, Khater L, Ramos $\mathrm{CHI}$, da Silva Ana CR, Farah CS: Identification of new proteinprotein interactions involving the products of the chromosome- and plasmid-encoded type IV secretion loci of the phytopathogen Xanthomonas axonopodis pv. citri. Journal of Bacteriology 2005, 187:23।5-2325.

52. Tatusov RL, Fedorova ND, Jackson JD, Jacobs AR, Kiryutin B, Koonin EV, Krylov DM, Mazumder R, Mekhedov SL, Nikolskaya AN, Rao BS, Smirnov S, Sverdlov AV, Vasudevan S, Wolf YI, Yin JJ, Natale DA: The COG database: an updated version includes eukaryotes. BMC Bioinformatics 2003, 4:4I.

53. Sambrook J, Fritsch EF, Maniatis T: Molecular Cloning - A Laboratory Manual. 2nd edition. New York: Cold Spring Harbor Laboratory Press; 1989.

54. Romeiro RS: Bactérias Fitopatogênicas. 2nd edition. Viçosa: Editora UFV; 2005.

Publish with Biomed Central and every scientist can read your work free of charge

"BioMed Central will be the most significant development for disseminating the results of biomedical research in our lifetime. "

Sir Paul Nurse, Cancer Research UK

Your research papers will be:

- available free of charge to the entire biomedical community

- peer reviewed and published immediately upon acceptance

- cited in PubMed and archived on PubMed Central

- yours - you keep the copyright
BioMedcentral 